Article

\title{
Organizational and Environmental Factors with the Mediating Role of E-Commerce and SME Performance
}

\author{
Arsalan Hussain (D), Arfan Shahzad (D) and Rohail Hassan *(D) \\ Othman Yeop Abdullah Graduate School of Business (OYAGSB), Universiti Utara Malaysia, \\ Sintok 06010, Kedah Darul Aman, Malaysia; arsalanhussaink9@gmail.com (A.H.); arfan@uum.edu.my (A.S.) \\ * Correspondence: rohail.hassan@uum.edu.my; Tel.: +60-11-16416168
}

Received: 18 November 2020; Accepted: 15 December 2020; Published: 17 December 2020

\begin{abstract}
The study investigates the mediating role of e-commerce through organizational and environmental factors with small and medium enterprises (SMEs) performance. The study follows a cross-sectional survey method approach. The study's theoretical foundation is based on the resource-based view (RBV) and diffusion of innovation (DOI) theory. The current research identifies four manufacturing SMEs' strata based on participation in the country's exports using a stratified proportional random sampling technique. The research questionnaires were distributed among 700 top and middle-level managers of manufacturing SMEs. The data were analyzed by applying partial least square structural equational modeling (PLS-SEM) to examine the relationship between the exogenous, mediator, and endogenous variables. The finding reveals that top management support and competitive pressure have a significant positive impact on the use of e-commerce direct and mediation. At the same time, the adoption cost and government support have an insignificant impact on e-commerce usage. This study results can be used to enhance the use of e-commerce in Pakistan's manufacturing SMEs to improve the country's overall exports.
\end{abstract}

Keywords: use of e-commerce; manufacturing SMEs; organizational; environmental; firm performance

\section{Introduction}

Before starting on firm performance, it is vital to highlight that since the 1930s, researchers and practitioners together have pursued to understand underlying drivers of innovation and its effect on firm performance. However, the quest to link innovation with firm performance is somewhat obtained by interpreting innovation as culture [1] and innovation as a technology adoption [2]. Although several scholars have focused on the current decade, there are plenty of gaps in our understanding of the link between technology innovation and firm performance [3]. Likewise, open innovation subsequently increases SMEs' performance; for instance, Alibaba.com has become the world's largest e-commerce global platform for SMEs [4]. The dynamic, open innovation has mainly three processes: the inside-out process, the outside-in process, and the coupled process. All three processes must cross the regional boundaries by focusing on environmental factors and internal and external characteristics to implement open innovation $[4,5]$ successfully. Thus, the study argues that the use and effective implementation of open innovation technology requires both the organizational and external environmental factors to implement digital technologies in the firm's innovation process.

In the modern era of digitalization, the evolved phenomenon of e-commerce, particularly in emerging markets, is growing rapidly, and enterprises are starting to prefer to buy and sell online. The more significant economies of developing countries, India and China, are shifting their operations day by the day from conventional businesses to click-and-mortar. The Indian e-commerce market growth is anticipated to reach 64 billion US dollars by the end of 2020 [5]. Likewise, according to China's online trade market data, China has already reached a 574 billion US dollars market in 2018 [6]. 
Likewise, the fast-growing development in the e-commerce market alters the ways to operate a business in large as well as small industries [7]. However, e-commerce usage in small and medium enterprises (SMEs) has significantly increased and is continuously making progress.

In the 21st century, SMEs are enhancing the sustenance and growth of numerous economies of the globe. For instance, according to the Asia pacific economic report, SMEs contribute over half of the employment and over 97\% of all businesses across Asia-Pacific Economic Cooperation (APEC) economies [8]. Additionally, SME's share in the GDP of APEC countries is ranging from 20 percent to 50 percent. Similarly, In Association of Southeast Asian Nations (ASEAN) countries, SMEs account for 63.3 percent of employment, and their share in total gross value is around 42.2 percent [9]. In the same way, Zafar and Mustafa [10] said, on average, in low-income countries, SMEs contribute approximately $70 \%$ in employment and 60\% in the country's GDP. Moreover, in middle-income countries, SMEs are contributing $95 \%$ to employment and $70 \%$ to GDP. Hence, it is depicted that SMEs are equally important for every economy of the world.

In addition to GDP, exports are considered another critical factor analyzing the economic growth of any country. SMEs' participation can also escalate the country's exports [11]. Though in regional countries like China, India, and Japan, SMEs contribute $60 \%, 37.5 \%$, and $55 \%$, respectively, of their exports. According to the World Trade Report (2016), SMEs' participation in exports of Pakistan was estimated at $24.8 \%$, which is very low compared to the regional competitors. Hence, Pakistani SMEs are going through many challenges restricting their development in the long term [12]. Likewise, the adoption of new technology is an essential challenge faced by Pakistani SMEs.

Theoretically, the study deals with combining the disintegrated scholarly work about the TOE model on e-commerce usage. Previous scholars also elucidate the importance of technology innovation change with the significance of the factors, i.e., organizational and environmental [13]. Concerning the theoretical contribution of e-commerce usage, its integration as a mediator adds to a vital inclusion. In addition to that, drawing from the RBV perspective, the present study contributes by providing several theoretical relationships between TOE model resources and e-commerce usage as capability.

Practically, SMEs are embracing innovation activities to improve production processes [14]. There have been numerous studies on the adoption of e-commerce in the developed countries, but it is still at the earlier stage in developing countries [15]. In addition, many developing countries are still far behind in the adoption of e-commerce [16]. Similarly, Pakistan is also at the initial stage in the use of e-commerce [17].

According to the Global Competitiveness Report (2018), Pakistan is placed at 127 out of 140 states in terms of information communication technology (ICT) adoption. According to State Bank of Pakistan (SBP) (2019), economic experts forecasted that e-commerce sales would reach 1 billion US\$ by the end of the fiscal year 2020 [18]. Likewise, Table 1 shows the negative growth rate change in exports of manufacturing industries of Pakistan. Therefore, e-commerce usage in Pakistani SMEs needed further investigation, and it is vital to consider organizational and environmental factors for successful usage of technology like e-commerce in SMEs [19]. Thus, the current study aims to contribute to the existing knowledge by using e-commerce as a mediating variable between organizational and environmental factors and SMEs' performance.

Table 1. Manufacturing industries' growth in exports of Pakistan.

\begin{tabular}{cc}
\hline $\begin{array}{c}\text { Percentage Growth Change in Exports of } \\
\text { Manufacturing Industries of Pakistan }\end{array}$ & 2018-2019 (Percentage Change) \\
\hline Textile industry & 0.08 \\
Sports goods industry & -9.04 \\
Surgical industry & -1.46 \\
Leather industry & -8.41 \\
Chemical and pharma & 5.68 \\
Engineering goods & -10.81 \\
Cement & 32.81 \\
Carpet rugs and metals & -12.5 \\
\hline
\end{tabular}


In Pakistan's manufacturing SMEs, it is needed to study the surgical industry in terms of technology usage like e-commerce. The surgical industry's contribution to total exports of the country is decreasing compared to the previous years. Pakistan's surgical instrument industry contributes 284.9, 254.4, 262.7, and 221.7 million US dollars in total exports of 2014, 2015, 2016, and 2017, respectively. In a similar vein, in the year 2018-2019, it is evident that there is a negative change of 1.46 percent in terms of exports' growth (Pakistan Bureau of Statistics, 2019). Likewise, there was a slight increase of 0.5 percent in sports goods SMEs in 2017-2018. The reason was the use of Pakistani football in Fédération Internationale de Football Association (FIFA) World Cup 2018. Unfortunately, again in the fiscal year 2018-2019, sports goods growth declined by 9 percent and 7.35 percent in terms of exports. In addition to sports goods, the leather industry's export growth also had a negative change of 8.41 percent in the fiscal year 2019. Similarly, the exports of textile manufacturers witnessed a slight growth of 0.1 percent and still stood at US\$ 9.99 billion in the fiscal year 2019 as compared to the US\$ 9.98 in the fiscal year 2018 [20].

The research findings insights about organizational and environmental factors through the indirect relation of e-commerce usage to SMEs' performance. The empirical investigation reveals that top management support and competitive pressure have a significant relationship direct as well as an indirect effect of the use of e-commerce as a mediation on firm performance [21,22]. However, adoption cost and government support do not appear statistically significant with e-commerce usage.

The remainder of this research consists of four sections. In the second section, the study highlights the detailed literature review and TOE model factors with the use of e-commerce and SMEs' performance. Section 3 focuses on the research methodology, which comprises sample size, data collection tools, and analysis. In the next Section 4, it will be interesting to read about the research's analysis and key findings. Section 5 ends up with the remarkable conclusion and limitations of the study.

\section{Literature Review}

\subsection{SMEs Performance}

SMEs' performance is considered a significant indicator of the effectiveness of organizations. SME's performance refers to an indicator consists of market share, firm profitability, and growth of the firm in which profitability and firm growth are necessary elements of SMEs' performance, and these elements are used to measure the effectiveness [23]. SMEs' performance was used as an indicator to assess the businesses' growth in an economy. SMEs' performance is one of the major concerns in today's businesses [24]. Moreover, the performance of SMEs is essential for for-profit organizations [25]. SMEs' performance is an essential indicator of attaining the firm [26]. Most of the prior researchers paid less attention to which indicators should be included in SMEs' performance and how SMEs' performance should be measured [26]. Mainly scholars have measured the SME's performance with profit, survival, value, growth, and public image [27].

\subsection{B2B E-Commerce}

In a broader sense, previous business to business (B2B) electronic commerce adoption research has investigated the issues from a range of theoretical foundations. For instance, researchers have explored how technology, organization, and environmental (TOE) context factors examined the adoption/usage of B2B electronic commerce [28]. The main advantages of using B2B e-commerce include acquiring substantial returns by increasing performance, revenue, new business opportunities, reducing inventory, and improving customer relations [29]. Currently, Pakistan is far behind in electronic commerce usage from regional countries like Turkey, China, and India [30]. In 2019, Pakistan's Internet users' number was estimated to increase to 56 Million. Therefore, the present study addresses this problem by proposing the mediating role of the use of e-commerce with TOE model factors. 


\subsection{Adoption Cost}

Previous literature recognized that adoption cost has two streams related to technology innovation that are positive and negative [31]. In addition, the innovation's relative cost is more critical for small firms as compared to the large firm due to the less availability of the resources, such as finance, labor, and material [32]. Opposing this, the relationship between transaction costs and firm performance is negatively associated [33]. However, the direct influence of adoption cost on firm performance is a missing link. Therefore, more insights require at the firm level to identify the relationship between productivity, innovation, and operational efficiency. Different types of innovation costs have a different significant impact on business performance [34]. Hence, the direct relationship between adoption cost and firm performance is still in the infancy stage in the literature.

\subsection{Top Management Support}

Top management usually makes timely decisions to achieve the firm's ultimate goals; thus, the possible benefits and hurdles in taking the tough decision of adopting new technology like e-commerce. As defined in previous literature, TMS and encouragement are vital criteria for the adoption of IS technology, including e-commerce [35]. Similarly, top management knowledge related to the benefits of the adoption also creates substantial value. At the same time, it is crucial in the planning and defining role of information technology (IT) in the firm [36]. Moreover, the organization's new technology will be more successfully implemented if its employees recognize its adoption returns and support the managers [37]. Additionally, top management support is also helpful in reducing the employees' resistance to change. Several other factors like manager's attitudes towards IT, innovativeness, experiences, and IT knowledge directly affect SMEs' adoption process. Therefore, TMS is a crucial factor in e-commerce, and untimely, it may increase SMEs' performance in Pakistan.

\subsection{Government Support}

It is indisputable that government agencies are a well-established factor for organizational innovativeness [38]. In literature, government support has been measured in terms of two indicators. The first indicator is related to government availability to technology usage like the Internet. The second indicator is associated with government encouragement and assistance to encourage SMEs for e-commerce adoption. Notably, ref. [39] have investigated that businesses operated under restrictive government policies are less likely to adopt IT adoption. In addition, ref. [40] has submitted in their findings that government, through the influence of regulation, can positively as well as negatively impact the adoption of information technology innovation. Similarly, ref. [41] argues that one of the critical and influencing drivers of Internet commerce adoption is government support while investigating the TOE drivers of e-commerce adoption. Therefore, in the current study, government support is expected as an influencing factor for Pakistani SMEs.

\subsection{Competitive Pressure}

Competitive pressure refers to the "pressure felt by the competitors within the same industry" [39]. In previous literature, it is argued that competitive pressure affects technology adoption when a firm identifies that this adoption of technology leads towards competitive advantage and, ultimately, firm performance [42]. The general view held by all economists is that competition increases the chances of adoption of an innovation. It was argued in the literature that IT adoption had affected the competition in three ways; by changing the rule of competition, industry structure, and by providing new business methods in the industry. Previous studies have shown that competition intensity is positively influenced by the degree of e-commerce adoption [43]. Therefore, the present study has created a missing link between competitive pressure and firm performance through the use of e-commerce. 


\subsection{Theoretical Foundation and Framework}

According to the diffusion of innovation (DOI) theory, innovation is defined as "an idea, practices, or object that is perceived to be new by an individual or another unit of adoption" [44]. While diffusion refers to "the process by which an innovation is communicated through certain channels over time among the member of a social system" [44]. Similarly, Roger explains that diffusion is often related to the efforts to extend the innovation by good listeners by using the communication channels. However, adoption is more associated with the decision to agree and use innovation; for instance, e-commerce usage [45].

The TOE framework is also applied in numerous studies related to technology innovation and technology adoption/usage studies. For instance, electronic data interchange (EDI) adoption, e-market adoption, web 2.0, and enterprise resource planning (ERP) adoption [46-49]. However, the present study focuses on top management support (TMS) and adoption cost (AC) as an organizational context. Likewise, government support (GS) and competitive pressure (CP) as environmental factors.

In addition to TOE and DOI theories, a resource-based view (RBV) is also applied in numerous technology usage/adoption studies. In this study, RBV is employed as the underpinning theory. The primary contention of the RBV theory is resource heterogeneity, that is, capabilities, different resources, and immobility of the firm [50]. These unique resources consist of specific characteristics like economically valuable, relatively scarce, difficult to imitate by competitors, and non-substitutable by other market players. Firms have different resources and efficiently and effectively utilize their resources to gain a competitive advantage [51]. The present study has contributed to the RBV theory by considering the use of e-commerce as a capability to get a competitive advantage over rivals.

Theoretically, previous scholars have discussed blockchain adoption [52], cloud ERP adoption [53], e-government usage [54]. Moreover, it is suggested that e-commerce usage/adoption as a mediator needed further research, particularly for developing countries [16]. Moreover, very few studies have looked into the TOE model's organizational and environmental dimensions [55] combined with DOI and RBV theories. Hence, the highlighted practical and theoretical issues merit further study, and this study extends the existing knowledge by answering research questions in developing countries, particularly in manufacturing SMEs of Pakistan. The theoretical framework of the study is consisting of four independent variables, one mediating variable, and one dependent variable, as shown in Figure 1.

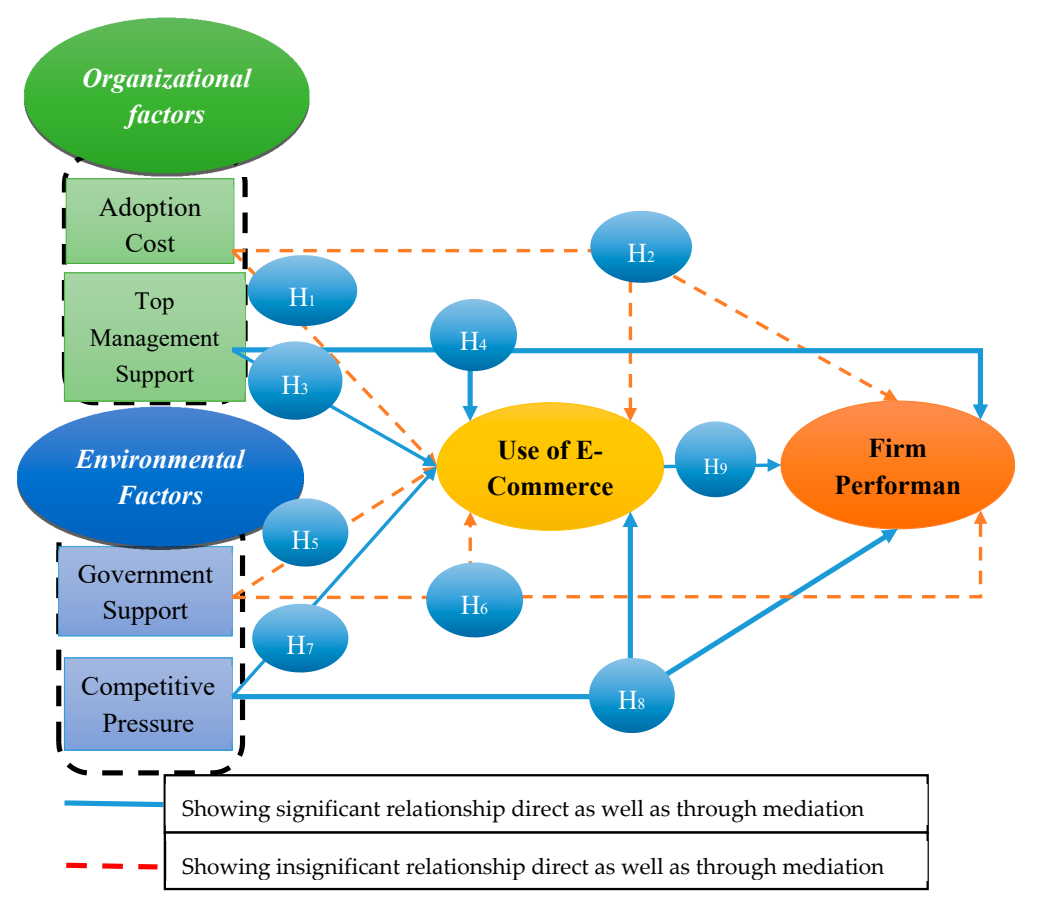

Figure 1. Theoretical framework. Source: authors. 


\subsection{Hypotheses Development}

\subsubsection{Adoption Cost, Use of E-Commerce, and Firm Performance}

The cost associated with the usage of e-commerce is measured as an influencing factor in SMEs and is known as adoption cost [56,57]. At the same time, in the literature, it is argued that the less cost of adopting technology, the more frequently it will be implemented in the organization [58,59]. Previous literature recognized that adoption cost has two streams related to technology innovation that are positive and negative [31]. The innovation's relative cost is more critical for small firms than large firms [60]. This is because of less resource availability in small and medium firms, such as finance, labor, and material [32]. In addition, there is a significant association between IT investment and firm performance [61].

Moreover, the literature suggested that several factors affect open innovation and SMEs performance, such as external networking, which is necessary to market B2B global market, and available resources like the cost of adopting a particular technology innovation [62]. On the other hand, there is a negative relationship between transaction costs and firm performance [33]. However, the direct influence of adoption cost on firm performance is a missing link. Therefore, more insights require at the firm level to identify the relationship between productivity, innovation, and operational efficiency. Different types of innovation costs have a different significant impact on business performance [34]. Hence, the indirect relationship between adoption cost and firm performance through e-commerce is still in the literature's infancy stage. The discussion formulates the below hypotheses:

Hypothesis 1. Adoption cost has a negative influence on the use of e-commerce.

Hypothesis 2. Use of e-commerce mediates the relationship between adoption cost and firm performance.

\subsubsection{Top Management Support, Use of E-Commerce, and Firm Performance}

Top Management Support refers to the firm's leadership that escalates the significance of e-commerce adoption and their commitment to it [63]. Previous empirical studies observed the positive relationship between top management support and firm performance [64,65]. Likewise, technological innovation (e-commerce) has been systematically influenced by top managers' support in the SME [66].

Top Management support to open innovation can be imitated for taking strategic and operational decisions. Further, management support can be reflected to provide awareness of how open innovation can further enhance the organization's innovativeness [67]. Thus, top management is an essential element that can force with or against the adoption process. If top management works positively to adopt new technology only, it may reduce organizational resistance for change like e-commerce [68-70]. The former scholars are more towards the subjective psychological state regarding the potentials of e-commerce. While the latter refers to the steps taken to enable e-commerce in their firms [71]. Hence, top management support is an indispensable factor and served as a strategic resource to increase firm performance [72]. Therefore, based on the stated arguments, the following hypotheses were established:

Hypothesis 3. Top management support has a positive influence on the use of e-commerce.

Hypothesis 4. Use of e-commerce mediates the relationship between top management support and firm performance.

\subsubsection{Government Support, Use of E-Commerce, and Firm Performance}

Literature reveals that SMEs' sectors are primarily influenced by governmental policies and lack of innovation implementation $[73,74]$. This implies that the government should take several corrective and preventive measures to solve numerous problems, such as establishing an R\&D department to compete in the international market and making technological advancements to improve products and services.

In the 21st century, open innovation is the primary concern of industries. However, Australian and Singapore governments have facilitated the promotion of online open innovation platforms [75]. 
However, there is very rare research available that identified the firm's performance with government support and innovation, particularly in developing countries [76]. However, previous studies have also used government support in innovation usage like e-marketing, e-government, e-banking, and e-learning [60,77-79]. Thus, all the above-discussed issues are causing a direct or indirect effect on SMEs' performance, which needs to be tested with the RBV theory. At what level government support impact the firm performance? Moreover, this literature is filled with the help of the current study. The discussion leads to the following hypotheses:

Hypothesis 5. Government support has a significant positive influence on the use of e-commerce.

Hypothesis 6. Use of e-commerce mediates the relationship between government support and firm performance.

\subsubsection{Competitive Pressure, Use of E-Commerce, and Firm Performance}

Competitive pressure refers to the "pressure felt by the competitors within the same industry" [39]. In previous literature, it is argued that competitive pressure affects technology adoption when a firm identifies that this adoption of technology leads towards competitive advantage and, ultimately, firm performance $[42,80]$. Similarly, the study shows that firms are moving towards innovation adoption as competitive pressure increases. However, the literature suggests that the pressure on SMEs has increased unprecedented challenges [81].

Moreover, open innovation is an approach that focuses on new ideas and knowledge generated from the outside environment of the firm, such as competitive pressure [82]. Likewise, a study by [83] indicated that the top market players could make industry standards, and these standers force other firms of the market to follow them. Therefore, it implies that to maintain the position of competitiveness, SMEs must adopt the technology to grab maximum market share both at local and international level and such activity upsurge the confidence level of the customers and help the company to increase their sales to pay back the investment in a short period $[47,84]$ which eventually increases firm performance [85-87]. The above discussion proposed the following hypotheses:

Hypothesis 7. Competitive pressure has a significant positive influence on the use of e-commerce.

Hypothesis 8. Use of e-commerce mediates the relationship between competitive pressure and firm performance.

\subsubsection{Use of E-Commerce has a Significant Positive Influence on Firm Performance}

The term open innovation has created a new value for a firm by combining technologies and markets such as inter-organizational networks and national innovation systems beyond the boundaries of the firm [4]. Consequently, open innovation dynamic capabilities allow firms to crab outbound opportunities by using information technology. Thus, the use of e-commerce as innovation openness can fascinate customer interaction with the seller globally, which eventually enhances the SMEs' performance.

In the past literature, e-commerce usage is considered a platform to interact with other business partners, which leads to firm performance [88]. Likewise, this usage is fascinating customer interaction with the seller locally and globally as well. Furthermore, [89] confirmed that the use of e-commerce had changed many operations in the business; it is not only changed the ways of selling, buying, and overall communication of business partners to change the business perspective from "production excellence" to "customer intimacy". Despite great attention by the government, the adoption of electronic commerce is still behind in developing countries. Moreover, [90] reported that e-commerce has a positive impact on operational performance.

On the contrary, Sila [91] studied the consequences of e-commerce usage and confirmed that e-commerce uses do not directly impact operational performance. Instead, it improves the performance of business operations first and later enhances operational performance. Therefore, the current study 
includes e-commerce usage as a mediator in the framework to help Pakistan's SME sector. In addition, to enhance the performance of SME's, all the factors were studied thoroughly with the help of previous literature to motivate the SME's to analyze the lacking in their firms and to adopt different ways and methods to resolve their current issues and maximize their profits, market share, financial position, and survival for the more extended period. The above discussion formulates the following hypothesis:

Hypothesis 9. Use of e-commerce has a significant positive influence on firm performance.

\section{Methodology}

\subsection{Research Design, Measures and Sampling Technique}

Research design can be referred to as a plan or procedure used to conduct the study, collect data, and analyses variables stated in the research problem. It is essentially an outline and plans to explore the research to answer the research questions. In this research, a cross-sectional survey method was used. Survey research analyses the association for different variables in the social system such as institutions, organizations, and communities. Moreover, the unit of analysis means the object that is studied in research [92]. The subject can be an individual, an organization, or a household relevant to the researcher's studies [93]. The study has used the organization as a unit of analysis, and SME managers working at the top and middle-level positions are considered respondents.

The present study has followed a closed-ended questionnaire composed of two sections: section one covers demographic information concerning respondents and their firms, while section two covers questions pertaining to constructs used in the research frameworks of the present study. In addition, a concise overview of both subsections is given as follows: Section A consists of six questions; four questions relate to the respondent's profile, including gender, age, education, and position in the organization's hierarchy; while the remaining two questions were related to the firm, i.e., industry type and experience of using e-commerce. Section B includes six adapted questionnaires from previously published studies; the scale of firm performance was modified in line with [94] and [95]; to measure adoption cost, three (03) items scale was taken from [96]; Likewise, four (04) element questionnaire to measure top management support was adapted from [97]; government support scale was adapted from [98] with four (04) items; competitive pressure is measured with the [95] scale of six (06) items; Use of e-commerce was assessed by adapting seven (07) items scale from [99].

There are about 3.8 million registered companies in Pakistan, including 90 percent of small and medium-sized companies across the country approximately [100]. The present study identifies four manufacturing SMEs' strata based on participation in the country's exports by using a stratified proportional random sampling. The total population of manufacturing SMEs that participated in exports of Pakistan is 6561, as shown in Table 2. However, 364 manufacturing SMEs were chosen according to the sample size table provided by [101]. To collect the research data, a total of 700 questionnaires were sent to the top and middle-level managers of selected manufacturing SMEs as shown in Table 3.

\subsection{Data Collection Procedure}

The researcher has collected the data with adapted questionnaires from the top and middle-level managers of Pakistan's targeted manufacturing SMEs. The questionnaire is constructed with a Likert scale of seven scales, anchored to "strongly disagree" (1) and "strongly agree" (7). The questions were structured to explore the mechanisms which will affect Pakistan's SMEs' performance and use of e-commerce. Precisely, the data for this study is collected for three and a half months, starting from April 2020. By keeping in view, the nature of the manufacturing firms' managers, the survey was conducted via the Google form; the questionnaire was shared by email (addresses taken from the Sialkot chamber of commerce) and WhatsApp community groups SMEs managers as presented in Table 4. 
Table 2. The population of the current study.

\begin{tabular}{cc}
\hline Manufacturing SMEs & Number of SMEs Participated in Exports \\
\hline Textile & 1304 \\
\hline Leather goods & 1540 \\
\hline Sports goods & 2071 \\
\hline Surgical instruments & 1646 \\
\hline Total & 6561 \\
\hline \multicolumn{2}{c}{ Source: [102]. }
\end{tabular}

Table 3. The sample size calculation is based on the sampling technique.

\begin{tabular}{ccc}
\hline Strata & Proportionate & Sample Size (S) \\
\hline Textile & $1304 / 6561=0.198$ & $700 \times 0.198=139$ \\
\hline Leather & $1540 / 6561=0.234$ & $700 \times 0.234=165$ \\
\hline Sports & $2071 / 6561=0.315$ & $700 \times 0.315=221$ \\
\hline Surgical & $1646 / 6561=0.250$ & $700 \times 0.250=175$ \\
\hline Total & & 700 \\
\hline
\end{tabular}

Table 4. Response rate of questionnaires.

\begin{tabular}{cc}
\hline No of Questionnaire & Response Rate \% \\
\hline Distributed & 700 \\
\hline Returned & 383 \\
\hline Incomplete & 15 \\
\hline Returned and usable & 364 \\
\hline Response rate percentage & $54.6 \%$ \\
\hline Usable response rate & $52.5 \%$ \\
\hline
\end{tabular}

\section{Data Analysis and Findings}

\subsection{Multivariate Skewness and Kurtosis}

The present study assessed the multivariate skewness as well as kurtosis by using web power software available at https://webpower.psychstat.org/models/kurtosis, as suggested by Sarstedt, Ringle [103] and Cain, Zhang [104] before further analysis. After analysis, the result revealed that the collected survey data were not multivariate normal; Mardia's multivariate skewness and kurtosis were $(\beta=2.80, p<0.01)$ and ( $\beta=48.98, p<0.01$ ) respectively, as shown in Figure 2. Therefore, in the present study, the researcher has used PLS-SEM by SmartPLS software due to the multivariate normality issue.

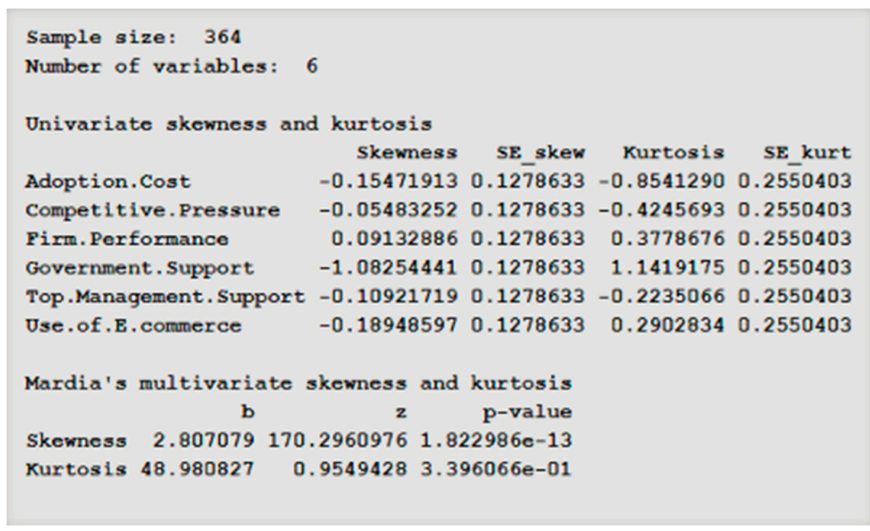

Figure 2. Mardia's multivariate skewness and kurtosis.

\subsection{Respondents Profile}

This section explains the profile of the respondents of the current study as shown in Table 5. The demographic information covers information related to respondents and their firm. 
Table 5. Demographic data and respective percentages.

\begin{tabular}{ccc}
\hline Demographics & Frequency & Percentage (\%) \\
\hline Gender & & \\
Male & 198 & 54.39 \\
Female & 166 & 45.60 \\
Age group & & \\
21 to 30 years & 124 & 34.0 \\
31 to 40 years & 152 & 41.7 \\
40 years and above & 88 & 24.17 \\
Experience in using e-commerce \\
Less than 1 year & 164 & 45.05 \\
More than 1 to 2 years & 112 & 30.7 \\
More the 3 & 88 & 24.1 \\
\hline
\end{tabular}

\subsection{Descriptive Analysis of Latent Construct}

The descriptive statistic in Table 6 exhibited that scores related to mean, minimum, maximum, and standard deviation values were calculated on a Likert scale ranging from 1 (Strongly disagree) to 7 (Strongly agree). Hence, descriptive statistics show that mean values ranging from 4.36 to 5.44 , and standard deviation values range from 0.91 to 1.43. Moreover, Cronbach's alpha results are in line with the standard values, i.e., at least 0.65 is considered average reliability, and 0.70 or higher indicates that the instrument has a better reliability standard $[105,106]$.

Table 6. Descriptive statistics and Cronbach's alpha.

\begin{tabular}{cccccc}
\hline & Min & Max & Mean & SD & Cronbach's Alpha \\
\hline Adoption cost & 1 & 7 & 4.466 & 1.432 & 0.773 \\
Firm performance & 1 & 7 & 4.638 & 0.965 & 0.863 \\
Top management support & 1 & 7 & 4.365 & 1.139 & 0.967 \\
Government support & 1 & 7 & 5.441 & 0.916 & 0.841 \\
Competitive pressure & 1 & 7 & 4.783 & 0.965 & 0.809 \\
Use of e-commerce & 1 & 7 & 4.809 & 0.96 & 0.856 \\
\hline
\end{tabular}

\subsection{Assessment of Measurement Model}

The present research examined the validity and internal consistency reliability of the model to evaluate the outer model, also known as the measurement model [107] and it is shown in Figure 3.

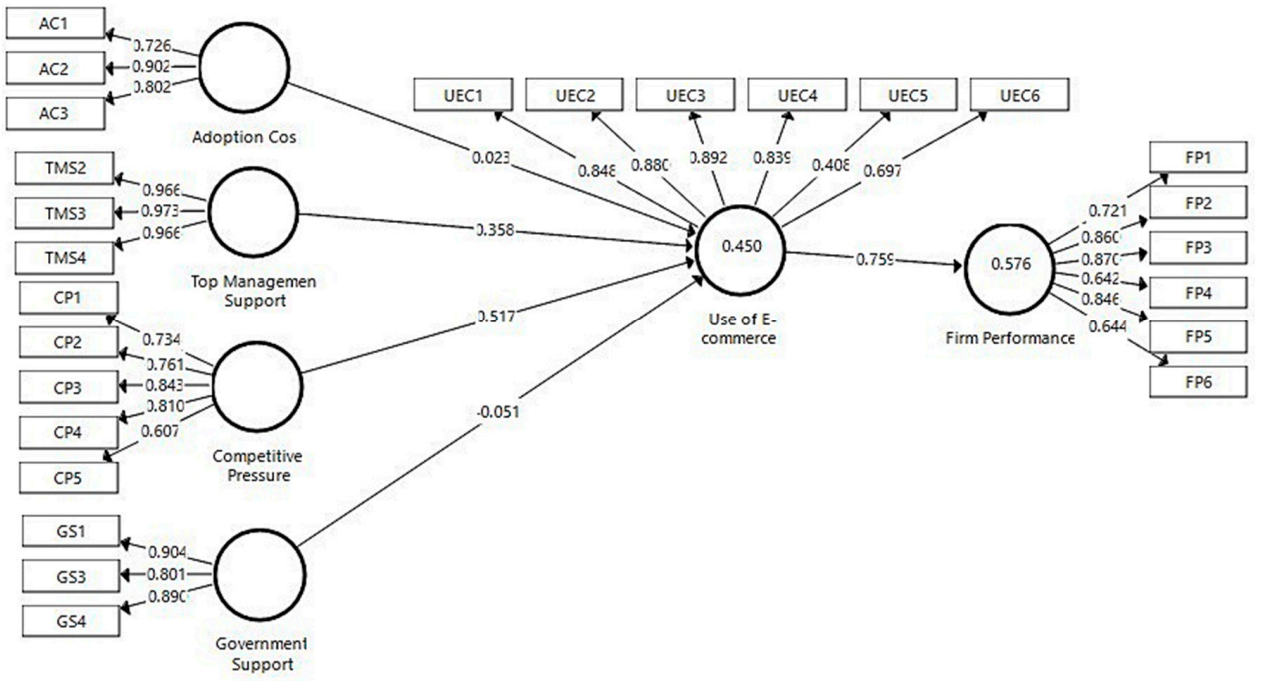

Figure 3. The PLS algorithm of the measurement model.

\subsubsection{Internal Consistency Reliability and Convergent Validity}

The composite reliability (CR) of the model was tested to measure the internal consistency reliability. Table 7 showed that all values are above 0.60 , which fulfilled the criteria [108]. Likewise, convergent validity is elucidated by [109] as "the degree to which a latent construct explains the 
variance of its indicators." Moreover, Table 7 shown that $50 \%$ of each variance is attained by each construct (i.e., AVE is equal and greater than 0.50), which is above the threshold value given by [109].

Table 7. Reliability and validity results.

\begin{tabular}{|c|c|c|c|c|}
\hline Construct & Items & Loadings & Composite Reliability (CR) & Average Variance Extracted (AVE) \\
\hline \multirow{3}{*}{ Adoption cost } & $\mathrm{AC} 1$ & 0.726 & 0.853 & 0.661 \\
\hline & AC2 & 0.902 & & \\
\hline & $\mathrm{AC} 3$ & 0.802 & & \\
\hline \multirow[t]{5}{*}{ Competitive pressure } & $\mathrm{CP} 1$ & 0.734 & 0.868 & 0.571 \\
\hline & $\mathrm{CP} 2$ & 0.761 & & \\
\hline & $\mathrm{CP} 3$ & 0.843 & & \\
\hline & $\mathrm{CP} 4$ & 0.810 & & \\
\hline & CP5 & 0.607 & & \\
\hline \multirow{6}{*}{ Firm performance } & FP1 & 0.721 & 0.896 & 0.593 \\
\hline & FP2 & 0.860 & & \\
\hline & FP3 & 0.870 & & \\
\hline & FP4 & 0.642 & & \\
\hline & FP5 & 0.846 & & \\
\hline & FP6 & 0.644 & & \\
\hline \multirow{3}{*}{ Government support } & GS1 & 0.904 & 0.90 & 0.75 \\
\hline & GS3 & 0.801 & & \\
\hline & GS4 & 0.890 & & \\
\hline \multirow{3}{*}{ Top management support } & TMS2 & 0.966 & 0.978 & 0.937 \\
\hline & TMS3 & 0.973 & & \\
\hline & TMS4 & 0.966 & & \\
\hline \multirow[t]{6}{*}{ Use of e-commerce } & UEC1 & 0.848 & 0.898 & 0.608 \\
\hline & UEC2 & 0.880 & & \\
\hline & UEC3 & 0.892 & & \\
\hline & UEC4 & 0.839 & & \\
\hline & UEC5 & 0.408 & & \\
\hline & UEC6 & 0.697 & & \\
\hline
\end{tabular}

\subsubsection{Discriminate Validity}

The square root of AVE given by [110] defines discriminating validity. Furthermore, ref. [110] propose that the value of the AVE square root should be greater than the latent variables, which indicates a discriminating value. Table 8 revealed that all the diagonal values are greater than the other latent variable values. Likewise, the second criterion is to measure the validity of the constructs provided by [111,112], including the two commonly used parameters with the cutoff points HTMT.85 and HTMT.90, respectively, to evaluate the HTMT values. The values shown in Table 9 are less than the threshold values.

Table 8. Discriminate validity matrix.

\begin{tabular}{ccccccc}
\hline & $\begin{array}{c}\text { Adoption } \\
\text { Cost }\end{array}$ & $\begin{array}{c}\text { Competitive } \\
\text { Pressure }\end{array}$ & $\begin{array}{c}\text { Firm } \\
\text { Performance }\end{array}$ & $\begin{array}{c}\text { Government } \\
\text { Support }\end{array}$ & $\begin{array}{c}\text { Top Management } \\
\text { Support }\end{array}$ & $\begin{array}{c}\text { Use of } \\
\text { E-Commerce }\end{array}$ \\
\hline Adoption cost & 0.813 & & & & & \\
\hline Competitive pressure & 0.114 & 0.755 & & & & \\
\hline Firm performance & 0.010 & 0.364 & 0.770 & & & \\
\hline Government support & -0.063 & 0.018 & -0.023 & 0.866 & 0.968 \\
\hline Top management support & 0.003 & 0.132 & 0.666 & 0.011 & 0.426 & 0.779 \\
\hline Use of E-commerce & 0.087 & 0.567 & 0.759 & -0.040 & & \\
\hline
\end{tabular}

Table 9. Heterotrait-monotrait ratio of correlations (HTMT).

\begin{tabular}{|c|c|c|c|c|c|c|}
\hline & $\begin{array}{l}\text { Adoption } \\
\text { Cost }\end{array}$ & $\begin{array}{l}\text { Competitive } \\
\text { Pressure }\end{array}$ & $\begin{array}{c}\text { Firm } \\
\text { Performance }\end{array}$ & $\begin{array}{l}\text { Government } \\
\text { Support }\end{array}$ & $\begin{array}{l}\text { Top Management } \\
\text { Support }\end{array}$ & $\begin{array}{c}\text { Use of } \\
\text { E-Commerce }\end{array}$ \\
\hline \multicolumn{7}{|l|}{ Adoption cost } \\
\hline Competitive pressure & 0.140 & & & & & \\
\hline Firm performance & 0.053 & 0.422 & & & & \\
\hline Government support & 0.071 & 0.039 & 0.049 & & & \\
\hline Top management support & 0.053 & 0.156 & 0.821 & 0.040 & & \\
\hline Use of E-commerce & 0.100 & 0.709 & 0.836 & 0.056 & 0.458 & \\
\hline
\end{tabular}




\subsection{Structure Model}

After the measurement model, the next move was towards the structural model assessment. As discussed by [108], inner modeling is given in a structural model by considering path coefficients and $t$-values of direct and indirect relationships. In addition, ref. [113] suggested that the $t$-value should be greater than 1.64 to decide the significance relationship and further used in decision-making on the above-proposed hypotheses. Below Figure 4 shows the structure model of the study.

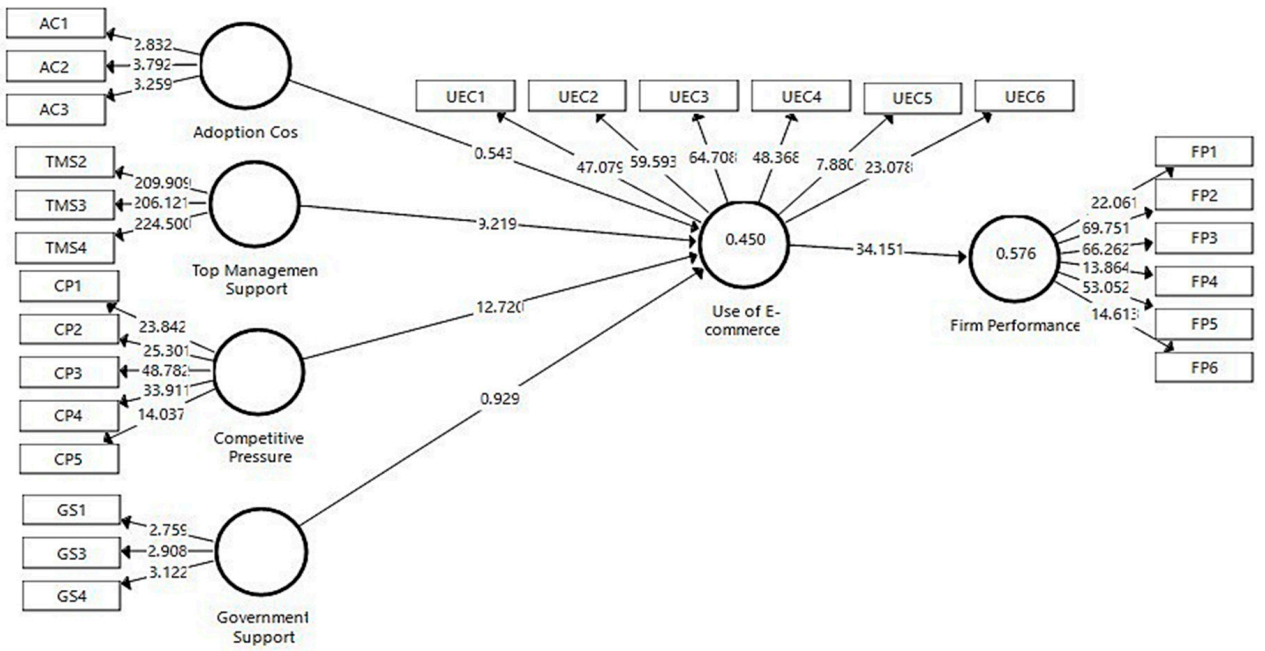

Figure 4. Assessment of structure model.

\subsubsection{Assessment of Structural Model}

Providently, Table 10 shows the hypotheses supported in the present study to have a t-value greater than 1.64. Therefore, three (03) out of the five (05) direct relationship hypotheses were supported in the current study. The first direct hypothesis is not supported, i.e., the direct impact from adoption cost (AC) to use of e-commerce (UEC) is not negatively significant (beta value $=0.023 ; \mathrm{T}=0.543 ; p>0.05$ ). Likewise, the result demonstrates that the second direct hypothesis, which is, top management support (TMS) has a significant positive impact on the use of e-commerce (UEC) (beta $=0.358 ; \mathrm{T}=9.219$; $p<0.05)$, supported. Similarly, the third direct relationship, which is government support, has a significant direct impact on e-commerce (beta $=-0.051 ; \mathrm{T}=0.929 ; p>0.05$ ), not supported. Fourth direct relationship, i.e., competitive pressure $(\mathrm{CP})$ has a significant positive effect on the use of e-commerce (UEC) (beta $=0.517 ; \mathrm{T}=12.72 ; p<0.05$ ), and therefore, supported. Lastly, the fifth direct hypothesis is supported, as the use of e-commerce has a positive direct impact on firm performance $(\mathrm{B}=0.759$; $\mathrm{T}=34.15 ; p<0.05)$.

Table 10. Hypotheses testing results (direct effect).

\begin{tabular}{ccccccccccc}
\hline Relationship & Std. Beta & Std. Error & T Values & $p$ Values & $\mathbf{2 . 5 0} \%$ & $\mathbf{9 7 . 5 0} \%$ & Decision & $\mathbf{R}^{\mathbf{2}}$ & $\mathbf{f}^{\mathbf{2}}$ & $\mathbf{Q}^{\mathbf{2}}$ \\
\hline AC $\rightarrow$ UEC & 0.023 & 0.043 & 0.543 & 0.587 & -0.126 & 0.082 & $\begin{array}{c}\text { Not } \\
\text { Supported }\end{array}$ & 0.576 & 0.001 & 0.331 \\
TMS $\rightarrow$ UEC & 0.358 & 0.039 & 9.219 & 0.000 & 0.281 & 0.433 & Supported & 0.450 & 0.229 & 0.258 \\
GS $\rightarrow$ UEC & -0.051 & 0.055 & 0.929 & 0.353 & -0.123 & 0.098 & Not & & 0.005 & \\
CP $\rightarrow$ UEC & 0.517 & 0.041 & 12.72 & 0.000 & 0.435 & 0.595 & Supported & & 0.471 \\
UEC $\rightarrow$ FP & 0.759 & 0.022 & 34.15 & 0.000 & 0.708 & 0.798 & Supported & & 0.360 & \\
\hline
\end{tabular}

Note: $\mathrm{AC}=$ adoption cost, $\mathrm{TMS}=$ top management support, $\mathrm{GS}=$ government support, $\mathrm{CP}=$ competitive pressure, $\mathrm{UEC}=$ use of e-commerce, $\mathrm{FP}=$ firm performance.

\subsubsection{Assessment of Coefficient of Determination $\left(R^{2}\right)$, Effect Size $\left(f^{2}\right)$, and Predictive Relevance $\left(R^{2}\right)$}

The coefficient of determination $\left(R^{2}\right)$ describes the degree of variation caused by all exogenous variables in the endogenous variable. In addition, ref. [109] presented the threshold values for the 
appropriate coefficient of determination values as $0.75,0.50$ as moderate, and 0.25 as a weak degree. The values displayed in Table 10 predicted that the coefficient of determination has moderate levels of predictive accuracy. After $\mathrm{R}^{2}$, the study investigated the effect size is to determine the influence of omitted exogenous variables on latent endogenous variables. In particular, it implies the difference in $\left(R^{2}\right)$ between the key effects in the model under review after the removal or presence of any specific exogenous variable [114]. To measure the effect size of a specific model, the threshold values range from $0.02,0.15$, and 0.35 for no, medium, and high effect sizes. The current study showed no and medium effect size of the studied model. Likewise, the acceptance level of predictive relevance $\left(\mathrm{Q}^{2}\right)$ above 0 indicates that exogenous variables have predictive significance for the model's endogenous variables [109]. Thus, it can be found in Table 10 that both the $\mathrm{Q}^{2}=0.331$ and $\mathrm{Q}^{2}=0.258$ values are greater than zero. Therefore, the current research model has sufficiently predictive relevance.

\subsection{Mediation Analysis}

The study also examined the indirect effects of independent variables through mediation. For mediation, several tests will be used to calculate mediation, such as the Sobel test by [115] and bootstrapping, which is given by [116], employed to calculate the indirect effect of a latent variable. Moreover, as recommended by [105], the bootstrapping technique is more appropriate for small sample size and works for multivariate models. Therefore, the current study employed bootstrapping (5000 subsamples) to calculate the indirect effect of the use of e-commerce.

Consequently, Table 11 presented that the mediation (indirect effect) of adoption cost with beta $=0.018$ and $t$-value of 0.541 does not support the mediating effect of the use of e-commerce with firm performance. Similarly, the mediation of the use of e-commerce in relationship with government support is also not significant mediation with beta $=-0.039$ and a $t$-value of 0.929 . However, the indirect effect with beta $=0.272$ and $t$-value of 8.177 is explained as significant mediation with top management support and firm performance. Lastly, the mediation effect of the use of e-commerce with competitive pressure and firm performance is also supported with beta $=0.393$ and a $t$-value of 12.955 .

Table 11. Mediation results.

\begin{tabular}{cccccccc}
\hline Relationship & Std. Beta & Std. Error & $\mathbf{t}$-Values & $\boldsymbol{p}$ Values & $\mathbf{2 . 5 0 \%}$ & $\mathbf{0 . 9 7 \%}$ & Decision \\
\hline $\mathrm{AC} \rightarrow \mathrm{UEC} \rightarrow$ FP & 0.018 & 0.033 & 0.541 & 0.588 & -0.094 & 0.062 & Not supported \\
$\mathrm{CP} \rightarrow \mathrm{UEC} \rightarrow$ FP & 0.393 & 0.030 & 12.955 & 0.000 & 0.331 & 0.450 & Supported \\
$\mathrm{GS} \rightarrow \mathrm{UEC} \rightarrow$ FP & -0.039 & 0.042 & 0.926 & 0.355 & -0.095 & 0.074 & Not supported \\
$\mathrm{TMS} \rightarrow \mathrm{UEC} \rightarrow$ FP & 0.272 & 0.033 & 8.177 & 0.000 & 0.207 & 0.338 & Supported \\
\hline
\end{tabular}

Note: $\mathrm{AC}=$ adoption cost, $\mathrm{TMS}=$ top management support, $\mathrm{GS}=$ government support, $\mathrm{CP}=$ competitive pressure, $\mathrm{UEC}=$ use of e-commerce, $\mathrm{FP}=$ firm performance.

\section{Discussion}

The study integrated the use of e-commerce innovation with SMEs' performance. The two aspects of the TOE model were successfully implemented. Therefore, the first contribution was the implementation in conjunction with the TOE model and technology usage (DOI theory), particularly the mediation of the use of e-commerce. The study demonstrates that two aspects of the TOE model, i.e., the organizational and environmental context factors, are essential to implement the technology usage. The study also provided a theoretical structure for manufacturing SMEs in Pakistan using the resource-based view (RBV). A total of nine (09) hypotheses were identified and formulated based on the research objectives and underlying issues. To test the theories, the statistical analysis was performed using SPSS $\mathrm{v} 25$ and PLS-SEM 3.3.2. The present study analysis and findings showed that out of nine (09) hypotheses, five (05) hypotheses have a significant impact on the use of e-commerce and firm performance.

The findings specify that a firm can benefit from using an open innovation process through the use of e-commerce platforms. As suggested by [117], customer and supplier interaction are highly important for open innovation. Though, a combination of the organizational and external environment with firm innovation can enhance manufacturing SMEs' global outreach. 
The results revealed that top management support (TMS) and competitive pressure (CP) is playing a significant role in the usage of e-commerce in Pakistani SMEs, and findings are consistent with the previous studies $[29,32,96,118,119]$. Thus, the present study considers the use of e-commerce as a strategic decision to improve Pakistani SMEs' overall performance. Further, the direct effect of e-commerce is also significant and consistent with past research [120,121]. The top management has the authority to allocate the financial and other resources needed to use e-commerce. The success of open innovation implementation is linked with the enthusiasm and support of top management to make strategic alliances and collaboration with global firms. Further, open innovation requires inter and intra-firm collaboration; therefore, SMEs need consistent leadership skills and efforts to ensure open innovation and firm growth.

Moreover, according to RBV theory, Barney [122] emphasized that firms should have unique resources and capabilities to bring towards competition in the industry to get a competitive advantage. Many studies have found consistent results with technology-enabled innovation and firm performance [123]. Further, the firms can achieve a competitive advantage if an enterprise bundles their resources and capabilities to become difficult for their competitors to imitate [124]. Moreover, some companies are focused on a full open innovation approach. At the same time, others are relying on close innovation. However, open innovation, like the use of e-commerce, is a continuous process that served as a capability towards a competitive advantage.

However, the present study analysis suggests that there is no support for the impact of adoption cost on the use of e-commerce. In contrast, cost remains one of the major barriers in literature in the adoption of technology [125]. The results revealed that the cost of adoption has an insignificant connection to the use of e-commerce. The reasoning behind the point out that the cost of human capital (e.g., training \& development), the re-engineering costs of the company's structure, and the cost of failure in the manufacturing production line $[126,127]$ are more essential considerations for technology usage rather than adoption cost. Further, the adoption cost factor does not influence the use of e-commerce in SMEs. As stated in the literature, open innovation collaborates and supports unused resources with other firms [128]. Likewise, with open innovation application, small and medium enterprises (SMEs) move towards a commission model such as third-party cloud platforms. In addition, the subscription to these e-commerce platforms is easy and cost-effective. Therefore, adoption cost does not find an influencing factor for the use of e-commerce in SMEs of Pakistan.

Moreover, the effect of government support (GS) on the use of e-commerce also has no significant relationship in the present study. Because the developing countries' government pushes and supports the adoption of e-commerce for large organizations in the following three ways. First, by providing incentives, second, by making specific policies and laws, creating skilled workers, and providing IT infrastructure $[129,130]$. Literature suggests that SMEs cannot pursue open innovation to commercialize its product to the global market without government support. Compared to large firms, SMEs require appropriate government policies and funding such as tax incentives, regulatory structure to avoid hacking and fraud, and e-commerce platforms to enhance open innovation in Pakistani manufacturing SMEs.

\subsection{A Holistic Comparison of Our Findings with Other Studies}

Prior scholars are focused mainly on two streams. First, determining factors of information communication technology (ICT) adoption [131]. Second, the usage of Innovation technology [132]. In literature, a lack of debate on e-commerce technology usage with firm performance. For instance, ref. [133] does not point out the link between sustainability and competitive capabilities in terms of environmental regulations and organizational drivers. Moreover, in the domain of technology innovation adoption, the researchers focused on one particular industry and context [134]. However, a firm's engagement in technology adoption is more concerned with community pressure and the economic risk of developing countries' enterprises [131]. Moreover, technology adoption studies are more towards adoption drivers, specifically [135]. The current study leads adoption to one step forward from innovation to performance effect. The previous research has also taken the use of sales revenue as the only performance indicator [81]. 
However, the current paper focused on financial as well as non-financial performance indicators. Past researchers are focused on the overall population of one sector, like the retail industry [136]. The present paper has employed four categories of manufacturing SMEs: textile, leather, sports, and surgical by applying a stratified proportionate random sampling technique.

\subsection{Implications of the Study}

Nonetheless, very few studies have investigated the theories of the TOE, DOI, and RBV as a combined theoretical consideration. Moreover, the study contributes by introducing the role of the use of e-commerce as a mediating variable between TOE factors and firm performance. The introduction and usage of e-commerce is key to enhancing efficiency during the era of digitalization. This study has a practical implication by using the TOE model, which is vivacious for the use of e-commerce, which ultimately leads to improved performance of Pakistani small and medium businesses. Moreover, the significant direct and indirect relationship with the use of e-commerce also calls upon the SME managers' attention towards the availability of such resources (independent variables) before implementing e-commerce in their organizations. Hence, this study has tried to explain the essential underlying factors and capabilities to convert the firm from the traditional way of doing business to click and mortar using e-commerce.

\subsection{Limitations and Future Research Recommendations}

The present research respondents belong to manufacturing firms, and the study's presence is beneficial only to small and medium-sized firms in developing countries. To increase the generalizability of the research, the study should have carried out through manufacturing SMEs in low-income countries around the globe. Future work should also fit the theoretical basis of dynamic capability theory by considering internal and external dynamic resources to achieve a competitive advantage.

\subsection{Conclusions}

The practice to implement the use of e-commerce in this era of digitization is indispensable and is of the essence during the progression of modern time. Based on technological and environmental specific factors in Pakistani manufacturing firms' context, this study is vivacious for e-commerce usage. The implementation of e-commerce will contribute to the upsurge in Pakistani manufacturing SMEs' performance in the long run. The present study contributes by providing useful guidelines for the policymakers, government regulators, and top management. These sets of bodies make a successful effort to target implementing the e-commerce usage in Pakistani manufacturing SMEs.

The research findings suggest that academic researchers and practitioners look at underlying resources and capabilities related to organizational and environmental factors before implanting e-commerce usage. Moreover, instead of motivating firms to use e-commerce only because other market players are doing so, the author has reached the point that enterprises should have a clear purpose before deciding to use e-commerce. It should align with the firms' strategy and objectives.

Author Contributions: Conceptualization, A.H., A.S. and R.H.; methodology, A.H., A.S. and R.H.; validation, A.H., A.S. and R.H.; writing—original draft preparation, A.H.; writing-review and editing, A.H., A.S. and R.H.; visualization, A.H., A.S. and R.H.; supervision, A.S. and R.H. All authors have read and agreed to the published version of the manuscript.

Funding: This research received no external funding.

Acknowledgments: We would like to pay to thanks the reviewers for their valuable reviews of the manuscripts. The highlighted issues helped improve the quality of the paper. Also, we would also like to thank Othman Yeop Abdullah Graduate School of Business (OYAGSB), Universiti Utara Malaysia (UUM) for the support and growing culture of the research.

Conflicts of Interest: The authors declare no conflict of interest. 


\section{References}

1. Lounsbury, M.; Cornelissen, J.; Granqvist, S.; Grodal, N. Culture, innovation and entrepreneurship. Innovation 2019, 21, 1-12. [CrossRef]

2. Hsu, H.-Y.; Liu, F.H.; Tsou, H.-T.; Chen, L.-J. Openness of technology adoption, top management support and service innovation: A social innovation perspective. J. Bus. Ind. Mark. 2019. [CrossRef]

3. Roach, D.C.; Ryman, J.A.; Makani, J. Effectuation, innovation and performance in SMEs: An empirical study. Eur. J. Innov. Manag. 2016, 19, 214-238. [CrossRef]

4. Yun, J.J.; Zhao, X.; Park, K.; Shi, L. Sustainability Condition of Open Innovation: Dynamic Growth of Alibaba from SME to Large Enterprise. Sustainability 2020, 12, 4379. [CrossRef]

5. Dutta, P.; Mishra, A.; Khandelwal, S.; Katthawala, I. A multiobjective optimization model for sustainable reverse logistics in Indian E-commerce market. J. Clean. Prod. 2020, 249, 119348. [CrossRef]

6. Lu, S.; Yang, L.; Liu, W.; Jia, L. User preference for electronic commerce overpackaging solutions: Implications for cleaner production. J. Clean. Prod. 2020, 120936. [CrossRef]

7. Ozturk, A.B. Customer acceptance of cashless payment systems in the hospitality industry. Int. J. Contemp. Hosp. Manag. 2016, 28, 801-817. [CrossRef]

8. APEC. Asia Pacific Economic Coorporation Report; Economic Committee(EC): Bruxelles, Belgien, 2018.

9. ASEAN. SME Policy Index; OECD/ERIA: Jakarta, Indonesia, 2018; Available online: https://doi.org/10.1787/ 9789264305328-en (accessed on 3 November 2020).

10. Zafar, A.; Mustafa, S. SMEs and its role in economic and socio-economic development of Pakistan. Int. J. Acad. Res. Account. Financ. Manag. Sci. 2017, 7, 195-205. [CrossRef]

11. Dar, M.S.; Ahmed, S.; Raziq, A. Small and medium-size enterprises in Pakistan: Definition and critical issues. Pak. Bus. Rev. 2017, 19, 46-70.

12. Raza, S.; Minai, M.S.; Zain, A.Y.M.; Tariq, T.A.; Khuwaja, F.M. Dissection of small businesses in pakistan: Issues and directions. Int. J. Entrep. 2018, 22, 1-13.

13. Zhang, Y.; Sun, J.; Yang, Z.; Wang, Y. Critical success factors of green innovation: Technology, organization and environment readiness. J. Clean. Prod. 2020, 121701. [CrossRef]

14. Baporikar, N.; Shikokola, S. Enhancing Innovation Adoption to Boost SMEs Performance. Int. J. Innov. Digit. Econ. 2020, 11, 1-20. [CrossRef]

15. Amornkitvikai, Y.; Lee, C. Determinants of E-Commerce Adoption and Utilisation by SMEs in Thailand; Economic Working Paper, No. 2020-01; ISEAS Yusof Ishak Institute: Singapore, 2020.

16. Hassen, H.; Rahim, N.H.A.; Shah, A. Analysis of models for e-commerce adoption factors in developing countries. Int. J. Perceptive Cogn. Comput. 2019, 5, 72-80. [CrossRef]

17. Moomal, A.; Masrom, M. ICT Development and Its Impact on e-Business and HRM Strategies in the Organizations of Pakistan. J. Adv. Manag. Sci. Vol. 2015, 3, 344-349. [CrossRef]

18. Nation. Developing E-commerce in Pakistan; The Nation: Manhatta, NY, USA, 2019.

19. Ocloo, C.E.; Xuhua, H.; Akaba, S.; Addai, M.; Worwui-Brown, D.; Spio-Kwofie, A. B2B E-commerce Adoption amongst manufacturing SMEs: Evidence from Ghana. Aust. J. Econ. Manag. Sci. 2018, 8, 126-146.

20. Economic Survey. Economic Survey of Pakistan; Finance Devision: Islamabad, Pakistan, 2019.

21. Luong, N.A.M.; Wang, L. Factors Influencing E-commerce Usage within Internationalisation: A study of Swedish Small and Medium-Sized Fashion Retailers. Master's Thesis, Uppsala University, Uppsala, Sweden, 2019.

22. Merhi, P.; Ahluwalia, P. Influence of safety nets, uncertainty avoidance, and governments on e-commerce adoption: A country-level analysis. J. Int. Bus. Stud. 2017, 35, 545-559.

23. Soininen, J.; Martikainen, M.; Puumalainen, K.; Kyläheiko, K. Entrepreneurial orientation: Growth and profitability of Finnish small-and medium-sized enterprises. Int. J. Prod. Econ. 2012, 140, 614-621. [CrossRef]

24. Shanmugam, J.K. The Impact of Information Technology (IT) Adoption towards Small Medium Enterprises (SMEs) Performance in Malaysia: The Role of IT Governance as Moderator. 2016. Available online: https://www.researchgate.net/publication/305865357_The_Impact_of_Information_Technology_IT_ Adoption_Towards_Small_Medium_Enterprises_SMEs_Performance_In_Malaysia_The_Role_of_IT_ Governance_as_Moderator (accessed on 3 November 2020).

25. Abu-Jarad, Y.; Yusof, N.; Nikbin, D. A review paper on organizational culture and organizational performance. Int. J. Bus. Soc. Sci. 2010, 1, 26-46. 
26. Richard, P.J.; DeVinney, T.M.; Yip, G.S.; Johnson, G. Measuring organizational performance: Towards methodological best practice. J. Manag. 2009, 35, 718-804. [CrossRef]

27. Prasanna, R.; Jayasundara, J.; Gamage, S.K.N.; Ekanayake, E.; Rajapakshe, P.S.K.; Abeyrathne, G. Sustainability of SMEs in the Competition: A Systemic Review on Technological Challenges and SME Performance. J. Open Innov. Technol. Mark. Complex. 2019, 5, 100. [CrossRef]

28. Villa, E.; Ruiz, L.; Valencia, A.; Picón, E. Electronic commerce: Factors involved in its adoption from a bibliometric analysis. J. Theor. Appl. Electron. Commer. Res. 2018, 13, 39-70. [CrossRef]

29. Alsaad, A.K.; Mohamad, R.; Ismail, N.A. The contingent role of dependency in predicting the intention to adopt B2B e-commerce. Inf. Technol. Dev. 2019, 25, 686-714. [CrossRef]

30. Khaskheli, A.; Jun, Y. A Review on the Importance of E-Commerce for SMEs in Pakistan. RISUS J. Innov. Sustain. 2016, 7, 11-17. [CrossRef]

31. Koh, S.; Simpson, M.; Padmore, J.; Dimitriadis, N.; Misopoulos, F. An exploratory study of enterprise resource planning adoption in Greek companies. Ind. Manag. Data Syst. 2006, 106, 1033-1059. [CrossRef]

32. Gunawardana, K. E-Commerce in Small and Medium Enterprises in Sri Lanka. In Start-Ups and SMEs: Concepts, Methodologies, Tools, and Applications; IGI Global: Hershey, PA, USA, 2020; pp. 634-649.

33. Gunday, G.; Ulusoy, G.; Kilic, K.; Alpkan, L. Effects of innovation types on firm performance. Int. J. Prod. Econ. 2011, 133, 662-676. [CrossRef]

34. Prajogo, D.I.; Oke, A. Human capital, service innovation advantage, and business performance. Int. J. Oper. Prod. Manag. 2016, 36, 974-994. [CrossRef]

35. Migdadi, M.M.; Abu Zaid, M.K.S.; Al-Hujran, O.S.; Aloudat, A.M. An empirical assessment of the antecedents of electronic-business implementation and the resulting organizational performance. Internet Res. 2016, 26, 661-688. [CrossRef]

36. Payton, F.C. Lessons learned from three interorganizational health care information systems. Inf. Manag. 2000, 37, 311-321. [CrossRef]

37. Ilin, V.; Ivetić, J.; Simić, D. Understanding the determinants of e-business adoption in ERP-enabled firms and non-ERP-enabled firms: A case study of the Western Balkan Peninsula. Technol. Forecast. Soc. Chang. 2017, 125, 206-223. [CrossRef]

38. Wang, C.; Kafouros, M.; Yi, J.; Hong, J.; Ganotakis, P. The role of government affiliation in explaining firm innovativeness and profitability in emerging countries: Evidence from China. J. World Bus. 2020, 55, 101047. [CrossRef]

39. Zhu, K.; Kraemer, K.L. Post-adoption variations in usage and value of e-business by organizations: Cross-country evidence from the retail industry. Inf. Syst. Res. 2005, 16, 61-84. [CrossRef]

40. Lai, K.H.; Ngai, E.W.T.; Cheng, T.C.E. Information technology adoption in Hong Kong's logistics industry. Transp. J. 2005, 44, 1-9.

41. Scupola, A. The adoption of Internet commerce by SMEs in the south of Italy: An environmental, technological and organizational perspective. J. Glob. Inf. Technol. Manag. 2003, 6, 52-71. [CrossRef]

42. Soto-Acosta, P.; Popa, S.; Palacios-Marqués, D. E-business, organizational innovation and firm performance in manufacturing SMEs: An empirical study in Spain. Technol. Econ. Dev. Econ. 2016, 22, 885-904. [CrossRef]

43. Porter, M. On Competition; Harvard Business Press: Brighton, MA, USA, 2008.

44. Rogers, E.M. Diffusions of Innovations, 5th ed.; Free Press: New York, NY, USA, 2003.

45. Bøving, K.B.; Bødker, K. Where is the Innovation? In IFIP International Federation for Information Processing; Springer: Berlin/Heidelberg, Germany, 2003; pp. 39-52.

46. Saldanha, T.J.V.; Krishnan, M.S. Organizational adoption of web 2.0 technologies: An empirical analysis. J. Organ. Comput. Electron. Commer. 2012, 22, 301-333. [CrossRef]

47. Kuan, K.K.Y.; Chau, P.Y.K. A perception-based model for EDI adoption in small businesses using a technology-organization-environment framework. Inf. Manag. 2001, 38, 507-521. [CrossRef]

48. Duan, X.; Deng, H.; Corbitt, B. Evaluating the critical determinants for adopting e-market in Australian small-and-medium sized enterprises. Manag. Res. Rev. 2012, 35, 289-308. [CrossRef]

49. Ramdani, B.; Chevers, D.; Williams, D.A. SMEs' adoption of enterprise applications: A technology-organisation-environment model. J. Small Bus. Enterp. Dev. 2013, 20, 735-753. [CrossRef]

50. Mata, F.J.; Fuerst, W.L.; Barney, J.B. Information technology and sustained competitive advantage: A resource-based analysis. MIS Q. 1995, 19, 487-505. [CrossRef] 
51. Hwang, D.; Min, H. Identifying the drivers of enterprise resource planning and assessing its impacts on supply chain performances. Ind. Manag. Data Syst. 2015, 115, 541-569. [CrossRef]

52. Valeri, M. Blockchain technology: Adoption perspectives in tourism. In Entrepreneurship and Organizational Change; Springer: Berlin/Heidelberg, Germany, 2020; pp. 27-35. [CrossRef]

53. Al-Shboul, M.A. Towards better understanding of determinants logistical factors in SMEs for cloud ERP adoption in developing economies. Bus. Process. Manag. J. 2019, 25, 887-907. [CrossRef]

54. Yera, A.; Arbelaitz, O.; Jauregui, O.; Muguerza, J. Characterization of e-Government adoption in Europe. PLOS ONE 2020, 15, e0231585. [CrossRef]

55. Depietro, R.; Wiarda, E.; Fleischer, M. The context for change: Organization, technology and environment. Process. Technol. Innov. 1990, 199, 151-175.

56. Sila, I. Factors affecting the adoption of B2B e-commerce technologies. Electron. Commer. Res. 2013, 13, $199-236$. [CrossRef]

57. Alam, S.S. Adoption of internet in Malaysian SMEs. J. Small Bus. Enterp. Dev. 2009, 16, 240-255. [CrossRef]

58. Premkumar, G.; Roberts, M. Adoption of new information technologies in rural small businesses. Omega 1999, 27, 467-484. [CrossRef]

59. Wymer, S.A.; Regan, E.A. Factors influencing e-commerce adoption and the use of small and medium businesses. Electron. Mark. 2015, 15, 438-453. [CrossRef]

60. Mohtaramzadeh, M.; Ramayah, T.; Jun-Hwa, C. B2B E-commerce adoption in Iranian manufacturing companies: Analyzing the moderating role of organizational culture. Int. J. Hum. Comput. Interact. 2018, 34, 621-639. [CrossRef]

61. Chen, Y.; Zhu, J. Measuring information technology's indirect impact on firm performance. Inf. Technol. Manag. 2004, 5, 9-22. [CrossRef]

62. Yoon, B.; Shin, J.; Lee, S. Open innovation projects in SMEs as an engine for sustainable growth. Sustainability 2016, 8, 146. [CrossRef]

63. Jitpaiboon, T.; Vonderembse, M.; Asree, S. The influence of top management support and information technology (IT) utilization on supply chain integration (SCI). Calif. J. Oper. Manag. 2010, 8, 1-19.

64. Popovič, A.; Hackney, R.; Tassabehji, R.; Castelli, M. The impact of big data analytics on firms' high value business performance. Inf. Syst. Front. 2018, 20, 209-222. [CrossRef]

65. Singh, S.K.; Gupta, S.; Busso, D.; Kamboj, S. Top management knowledge value, knowledge sharing practices, open innovation and organizational performance. J. Bus. Res. 2019. [CrossRef]

66. Hussein, L.A.; Baharudin, A.S.; Jayaraman, K.; Kiumarsi, S. B2B e-commerce technology factors with mediating effect perceived usefulness in Jordanian manufacturing SMES. J. Eng. Sci. Technol. 2019, 14, 411-429.

67. Barham, H.; Dabic, M.; Daim, T.; Shifrer, D. The role of management support for the implementation of open innovation practices in firms. Technol. Soc. 2020, 63, 101282. [CrossRef]

68. Tajudeen, F.P.; Jaafar, N.I.; Ainin, S. Understanding the impact of social media usage among organizations. Inf. Manag. 2018, 55, 308-321. [CrossRef]

69. Damanpour, F.; Schneider, M. Characteristics of innovation and innovation adoption in public organizations: Assessing the role of managers. J. Public Adm. Res. Theory 2008, 19, 495-522. [CrossRef]

70. Hameed, M.A.; Counsell, S.; Swift, S. A meta-analysis of relationships between organizational characteristics and IT innovation adoption in organizations. Inf. Manag. 2012, 49, 218-232. [CrossRef]

71. Liang, H.; Saraf, N.; Hu, Q.; Xue, Y. Assimilation of enterprise systems: The effect of institutional pressures and the mediating role of top management. MIS Q. 2007, 31, 59-87. [CrossRef]

72. Singh, S.K.; Del Giudice, M.; Tarba, S.Y.; De Bernardi, P. Top Management Team Shared Leadership, Market-Oriented Culture, Innovation Capability, and Firm Performance. IEEE Trans. Eng. Manag. 2019, 1-11. [CrossRef]

73. Lee, C.; Narjoko, A.N.; Oum, S. (Eds.) SMEs and Economic Integration in Southeast Asia; ISEAS Yusof Ishak Institute: Singapore, 2019.

74. Humphreys, P.; McAdam, R.; Leckey, J. Longitudinal evaluation of innovation implementation in SMEs. Eur. J. Innov. Manag. 2005, 8, 283-304. [CrossRef]

75. Yun, J.J.; Liu, Z. Micro-and Macro-Dynamics of Open Innovation with a Quadruple-Helix Model; Multidisciplinary Digital Publishing Institute: Basel, Switzerland, 2019.

76. Songling, Y.; Ishtiaq, M.; Anwar, M.; Ahmed, H. The role of government support in sustainable competitive position and firm performance. Sustainability 2018, 10, 3495. [CrossRef] 
77. Sánchez-Torres, J.A.; Arroyo-Cañada, F.-J.A.; Sandoval, A.V.; Sánchez-Alzate, J.A. E-banking in Colombia: Factors favouring its acceptance, online trust and government support. Int. J. Bank Mark. 2018, 36, 170-183. [CrossRef]

78. Kazungu, I.; Panga, F.P.; Mchopa, A. Impediments to adoption of e-marketing by Tanzanian small and medium sized enterprises: An explanatory model. Int. J. Econ. Commer. Manag. 2015, 6, 587-597.

79. Shahzad, A.; Hassan, R.; Aremu, A.Y.; Hussain, A.; Lodhi, R.N. Effects of COVID-19 in E-learning on higher education institution students: The group comparison between male and female. Qual. Quant. 2020, 1-22. [CrossRef]

80. Grandon, M. Theory-based instrumentation to measure the intention to use electronic commerce in small and medium sized businesses. J. Comput. Inf. Syst. 2004, 44, 44-57. [CrossRef]

81. Saridakis, G.; Lai, Y.; Mohammed, A.-M.; Hansen, J.M. Industry characteristics, stages of E-commerce communications, and entrepreneurs and SMEs revenue growth. Technol. Forecast. Soc. Chang. 2018, 128, 56-66. [CrossRef]

82. Dokukina, A.A.; Petrovskaya, I.A. Open Innovation as a Business Performance Accelerator: Challenges and Opportunities for the Firms' Competitive Strategy. In Proceedings of the International Science and Technology Conference “FarEastCon 2019”, Vladivostok, Russia, 1-4 October 2019; pp. 275-286.

83. Alzougool, B.; Kurnia, S. Electronic commerce technologies adoption by SMEs: A conceptual study. In Proceedings of the 19th Australasian Conference on Information Systems, Christchurch, New Zealand, 3-5 December 2008.

84. Gupta, P.; Seetharaman, A.; Raj, J.R. The usage and adoption of cloud computing by small and medium businesses. Int. J. Inf. Manag. 2013, 33, 861-874. [CrossRef]

85. Ortega, M.J.R. Competitive strategies and firm performance: Technological capabilities' moderating roles. J. Bus. Res. 2010, 63, 1273-1281. [CrossRef]

86. Rahim, F.B.T.; Bin Zainuddin, Y. The impact of technological innovation capabilities on competitive advantage and firm performance in the automotive industry in Malaysia. In AIP Conference Proceedings; AIP Publishing: Melville, NY, USA, 2019; Volume 2059, pp. 020030-1-020030-12.

87. Henseler, J.; Ringle, C.M.; Sinkovics, R.R. Exploration/exploitation innovation and firm performance: The mediation of entrepreneurial orientation and moderation of competitive intensity. J. Asia Bus. Stud. 2019, 13, 489-506. [CrossRef]

88. Kraemer, K.L.; Gibbs, J.; Dedrick, J. Impacts of globalization on e-commerce use and firm performance: A cross-country investigation. Inf. Soc. 2005, 21, 323-340. [CrossRef]

89. Rahayu, R.; Day, J. Determinant factors of e-commerce adoption by SMEs in developing country: Evidence from Indonesia. Procedia-Soc. Behav. Sci. 2015, 195, 142-150. [CrossRef]

90. Wiengarten, F.; Humphreys, P.; McKittrick, A.; Fynes, B. Investigating the impact of e-business applications on supply chain collaboration in the German automotive industry. Int. J. Oper. Prod. Manag. 2013, 33, $25-48$. [CrossRef]

91. Sila, I. Do organisational and environmental factors moderate the effects of Internet-based interorganisational systems on firm performance? Eur. J. Inf. Syst. 2010, 19, 581-600. [CrossRef]

92. Sekaran, U. Research Methods for Business: A Skill Building Approach, 4th ed.; John Wiley \& Sons: New York, NY, USA, 2004.

93. Rea, L.; Parker, R. Survey Research: A Comprehensive Guide; Jossey-Bass: San Francisco, CA, USA, 2005.

94. Deshpandé, R.; Farley, J.U. Measuring market orientation: Generalization and synthesis. J. Mark. Focused Manag. 1998, 2, 213-232. [CrossRef]

95. Jaworski, B.J.; Kohli, A.K. Market orientation: Antecedents and consequences. J. Mark. 1993, 57, 53-70. [CrossRef]

96. Al-Qirim, N. The adoption of eCommerce communications and applications technologies in small businesses in New Zealand. Electron. Commer. Res. Appl. 2007, 6, 462-473. [CrossRef]

97. Soliman, K.S.; Janz, B.D. An exploratory study to identify the critical factors affecting the decision to establish Internet-based interorganizational information systems. Inf. Manag. 2004, 41, 697-706. [CrossRef]

98. Looi, H.C. E-commerce adoption in Brunei Darussalam: A quantitative analysis of factors influencing its adoption. Commun. Assoc. Inf. Syst. 2005, 15, 61-81. [CrossRef]

99. Gibbs, J.L.; Kraemer, K.L. A cross-country investigation of the determinants of scope of e-commerce use: An institutional approach. Electron. Mark. 2004, 14, 124-137. [CrossRef]

100. SMEDA. State of SMEs in Pakistan; SMEDA: Lahore, Pakistan, 2018. 
101. Morgan, K. Sample Size Determination using Krejcie and Morgan; Kenya Projects Organization: Nairobi, Kenya, 2012; p. 1.

102. Exportsinfo. Available online: https://www.businessbook.pk/category/exporters-in-pakistan-1263 (accessed on 1 November 2020).

103. Sarstedt, M.; Ringle, C.M.; Hair, J.F. Partial least squares structural equation modeling. In Handbook of Market Research; Homburg, C., Klarmann, M., Vomberg, A., Eds.; Springer: Cham, Switzerland, 2017. [CrossRef]

104. Cain, M.K.; Zhang, Z.; Yuan, K.-H. Univariate and multivariate skewness and kurtosis for measuring nonnormality: Prevalence, influence and estimation. Behav. Res. Methods 2017, 49, 1716-1735. [CrossRef]

105. Sarstedt, M.; Ringle, C.M.; Hair, J.F. Partial least squares structural equation modeling (PLS-SEM) An emerging tool in business research. Eur. Bus. Rev. 2014, 26, 106-121. [CrossRef]

106. Sekaran, U.; Bougie, R.J. Research Methods for Business: A Skill Building Approach; John Wiley \& Sons: Hoboken, NJ, USA, 2016.

107. Sarstedt, M.; Ringle, C.M.; Hair, J.F. A primer on Partial Least Squares Structural Equation Modeling (PLS-SEM); SAGE publications: New York, NY, USA, 2016. [CrossRef]

108. Sarstedt, M.; Hair, J.F., Jr.; Cheah, J.H.; Becker, J.M.; Ringle, C.M. How to specify, estimate, and validate higher-order constructs in PLS-SEM. Australas. Mark. J. 2019, 27, 197-211. [CrossRef]

109. Hair, J.F.; Sarstedt, M.; Ringle, C.M.; Gudergan, S.P. Advanced Issues in Partial Least Squares Structural Equation Modeling; SAGE publications: New York, NY, USA, 2017.

110. Fornell, C.; Larcker, D.F. Structural Equation Models with Unobservable Variables and Measurement Error: Algebra and Statistics; Sage Publications: Los Angeles, CA, USA, 1981.

111. Kline, R.B. Principles and Practice of Structural Equation Modeling; Guilford publications: New York, NY, USA, 2015.

112. Gold, A.H.; Malhotra, A.; Segars, A.H. Knowledge management: An organizational capabilities perspective. J. Manag. Inf. Syst. 2001, 18, 185-214. [CrossRef]

113. Henseler, J.; Ringle, C.M.; Sinkovics, R.R. The use of partial least squares path modeling in international marketing. In New Challenges to International Marketing; Emerald Group Publishing Limited: Bingley, UK, 2009.

114. Hair, J.F.; Ringle, C.M.; Sarstedt, M. Partial least squares structural equation modeling: Rigorous applications, better results and higher acceptance. Long Range Plan. 2013, 46, 1-12. [CrossRef]

115. Baron, R.M.; Kenny, D.A. The moderator-mediator variable distinction in social psychological research: Conceptual, strategic, and statistical considerations. J. Personal. Soc. Psychol. 1986, 51, 1173-1182. [CrossRef]

116. Hayes, M.H. Statistical Digital Signal Processing and Modeling; John Wiley \& Sons: Hoboken, NJ, USA, 2009.

117. Grimsdottir, E.; Edvardsson, I.R. Knowledge management, knowledge creation, and open innovation in Icelandic SMEs. SAGE Open 2018, 8, 1-13. [CrossRef]

118. Vargas-Hernández, J.G.; Rosas, D.I.P. Policy recommendations for current relationship between electronic commerce and Mexican SMEs: Theoretical analysis under the vision based on the industry. J. Perspekt. Pembiayaan Dan Pembang. Drh. 2019, 6, 377-388. [CrossRef]

119. Shahzad, A.; Hassan, R.; Abdullah, N.I.; Hussain, A.; Fareed, M. Covid-19 impact on e-commerce usage: An empirical evidence from malaysian healthcare industry. Humanit. Soc. Sci. Rev. 2020, 8, 599-609. [CrossRef]

120. Sahu, S. Assessing the impact of e-business on organizational performance. Int. Res. J. Eng. Technol. 2016, 3, 836-838.

121. Ajao, B.F.; Oyebisi, T.O.; Aderemi, H.O. Implementation of e-commerce innovation on small enterprises in Nigeria. Int. J. Entrep. Small Bus. 2019, 38, 521-536. [CrossRef]

122. Barney, J. Firm resources and sustained competitive advantage. J. Manag. 1991, 17, 99-120. [CrossRef]

123. Liem, N.T.; Khuong, V.; Khanh, T. Firm Constraints on the Link between Proactive Innovation, Open Innovation and Firm Performance. J. Open Innov. Technol. Mark. Complex. 2019, 5, 88. [CrossRef]

124. Khana, M.P.; Talibb, N.A.; Kowangc, T.O. The Development of a Sustainability Framework via Lean Green Six Sigma Practices in SMEs Based upon RBV Theory. Development 2020, 12, 135-156.

125. Walker, J.H.; Saffu, K.; Mazurek, M. An empirical study of factors influencing e-commerce adoption/non-adoption in Slovakian SMEs. J. Internet Commer. 2016, 15, 189-213. [CrossRef]

126. Love, P.E.; Irani, Z.; Edwards, D.J. A seamless supply chain management model for construction. Supply Chain Manag. Int. J. 2004, 9, 43-56. [CrossRef]

127. Premkumar, G.; Ramamurthy, K.; Crum, M. Determinants of EDI adoption in the transportation industry. Eur. J. Inf. Syst. 1997, 6, 107-121. [CrossRef] 
128. Gkika, E.; Anagnostopoulos, T.; Ntanos, S.; Kyriakopoulos, G. User Preferences on Cloud Computing and Open Innovation: A Case Study for University Employees in Greece. J. Open Innov. Technol. Mark. Complex. 2020, 6, 41. [CrossRef]

129. Saprikis, V.; Vlachopoulou, M. Determinants of suppliers' level of use of B2B e-marketplaces. Ind. Manag. Data Syst. 2012, 112, 619-643. [CrossRef]

130. Thatcher, S.M.; Foster, W.; Zhu, L. B2B e-commerce adoption decisions in Taiwan: The interaction of cultural and other institutional factors. Electron. Commer. Res. Appl. 2006, 5, 92-104. [CrossRef]

131. Tutusaus, M.; Schwartz, K.; Smit, S. The ambiguity of innovation drivers: The adoption of information and communication technologies by public water utilities. J. Clean. Prod. 2018, 171, S79-S85. [CrossRef]

132. Aremu, A.Y.; Shahzad, A.; Hassan, S. The Impacts of Enterprise Resource Planning System Adoption on Firm's Performance among Medium Size Enterprises. Int. J. Inf. Syst. Soc. Chang. 2020, 11, 24-42. [CrossRef]

133. Aboelmaged, M.G. The drivers of sustainable manufacturing practices in Egyptian SMEs and their impact on competitive capabilities: A PLS-SEM model. J. Clean. Prod. 2018, 175, 207-221. [CrossRef]

134. Diana, G.C.; Jabbour, C.J.C.; Jabbour, A.B.L.D.S.; Kannan, D. Putting environmental technologies into the mainstream: Adoption of environmental technologies by medium-sized manufacturing firms in Brazil. J. Clean. Prod. 2017, 142, 4011-4018. [CrossRef]

135. Sayginer, C.; Ercan, T. Understanding determinants of cloud computing adoption using an integrated diffusion of innovation (doi)-technological, organizational and environmental (toe) model. Humanit. Soc. Sci. Rev. 2020, 8, 91-102. [CrossRef]

136. Luo, N.; Wang, Y.; Zhang, M.; Niu, T.; Tu, J.I. Integrating community and e-commerce to build a trusted online second-hand platform: Based on the perspective of social capital. Technol. Forecast. Soc. Chang. 2020, 153, 119913. [CrossRef]

Publisher's Note: MDPI stays neutral with regard to jurisdictional claims in published maps and institutional affiliations. 